Jens Schröter

\title{
Money and media theory
}

Unpublished raw translation, text, especially Part II, is revised (version 10/19) in comparison to the German original. This revised version is work in progress.

\section{Introductory Remarks}

«Money is the objective medium in which exchange values are immersed, and in which they acquire a form corresponding to their general determination.» ${ }^{1}$ Marx notes around $1857 / 58$, and even though the term 〈medium〉 cannot be found literally in Carl Menger's Principles of Economics of 1871, an essay on the «Origins of Money» from 1892 explicitly mentions the «medium of exchange». ${ }^{2}$ Obviously the concept of medium appeared in very different economic theories in the 19th century. This genealogy of the concept of medium does not appear in otherwise detailed historical accounts as for instance that of Stefan Hoffmann. ${ }^{3}$ Even though it is not a question of 〈revising the already multi-stranded and intricate history of the concept of medium, it is remarkable that Friedrich Kittler's much later definition of «media technologies» as techniques of «transmission, storage, processing of information» ${ }^{4}$ bears a certain resemblance to the «money functions〉 defined as standard today, namely money as a means of «exchange and payment» (transmission), «storage of value» (storage) and as an «unit of account» (processing). ${ }^{5}$

However, entirely different theoretical traditions also seem to have derived their concept of medium from money, such as sociological media theories: The structure-functionalist sociologist Talcott Parsons writes: «For me, money was [...] the model from which I started my reflections on media theory» ${ }^{6}$ Similarly, Marshall McLuhan, who in turn uses a different, more anthropologically toned concept of media, includes in his classic Understanding Media a chapter on money and even a chapter on the still economically virulent topic of automation. ${ }^{7}$ In his work, notes on labour, automation, money and value are scattered everywhere. ${ }^{8}$ In the chapter in Understanding Media in which media are defined as translators, he argues «all media are active metaphors in their power to translate experience into new forms ${ }^{9}$ and later he writes $«[\ldots]$ money is a metaphor» ${ }^{10}$ - which can mean that money is a medium or even more so: basically all media operate according to the principle of money, a thesis that McLuhan expressively reinforces elsewhere: "The Laws of Media [...] are quite simply this, that every medium exaggerates some function. [...] The simplest form I know to illustrate this principle, which works for all media, whether it's a teaspoon, corset or motor car, is money.»" ${ }^{11}$ 
For now, this admittedly somewhat associative list should suffice. It does, nonetheless, clearly show that there is a not so subliminal connection between - as one must formulate with caution - economic and media-theoretical discourse. ${ }^{12}$ It is apparent that money is at least an «area of intersection ${ }^{13}$ for these discourses, insofar as it is central to the (currently dominant forms of) economy, is already addressed as a medium in economics, and therefore is as such also a subject of media theory. Yet the latter is by no means self-evident: «Money simply does not occur in most of the widespread introductions to media studies.» ${ }^{14}$ Although there were - apart from McLuhan - a few authors who devoted themselves to money in a mediatheoretical oriented way, ${ }^{15}$ it is hardly a subject of media studies, despite its centrality. Even in pre-theoretical terms everyone seems to be aware that money is needed and that we cannot do without it. «Money makes the world go round〉. One can hardly resist the impression of a repression of money, which in turn creates a peculiar connection to economics, whose dominant - often called 〈neoclassical ${ }^{16}$ - form has itself repeatedly been accused of forgetting money. ${ }^{17}$ However, in addition to the dominant 〈orthodox〉 economy, there is also a whole range of 〈heterodox〉 economies, part of which have completely different theories of money. ${ }^{18}$ What do we do with this somewhat confusing situation? It seems apparent that a detailed examination of the discursive points of contact between the intrinsically heterogeneous field of media theory and the intrinsically heterogeneous field of economics is not possible here. Even with a focus on 〈money〉, its history, functions, concepts, theories, etc., such a discussion would still go far beyond the scope here.

This essay will start from another observation: In Geoffrey Ingham's Concepts of Money, a standard work on monetary theory that brings together texts from economics, sociology and political theory, the term 〈medium〉 appears twelve times in the foreword alone; ${ }^{19}$ yet, although the volume includes philosophical perspectives (an excerpt from Georg Simmel's Philosophy of Money), ${ }^{20}$ as well as chapters on Orthodox or Marxist monetary theory, on money as a unit of account, as credit, as a quantity generated by the state, however, there is no separate chapter on money as a sign system and/or medium. This does not seem to be a useful or even an existing perspective. ${ }^{21}$ Hence the question to be sketched out in this essay is: Can media theory contribute something to the discussion about money that other disciplines dealing with it (economics, sociology, political theory, philosophy) cannot?

Such a question would also reflexively test the capability of media studies in the interaction with other disciplines - if one would agree at all to regard 〈media studies` as a discipline of its own right, or rather as a kind of interdisciplinary meeting place, an 〈inter-discipline ${ }^{22}$ Finally, the situation is further complicated by the fact that, as indicated, various media concepts 
used in «media theory (which is not a uniform entity) are (or could be) derived directly or indirectly from money. Thus, the question of what media theory could contribute to the discussion of money would be recursive in some respects. One can begin with the observation that there was a sort of media discussion in the debate about money at a very early stage - as indicated: «that money is (at least also) a medium, the entire economic tradition already knew». ${ }^{23}$

In the second part of this text I will briefly present and discuss the probably most fundamental opposition in monetary theory: Namely between a theory of money as commodity and a theory of money as sign: «There are, as Schumpeter observed, «only two theories of money that deserve the name $[. .$.$] the commodity theory and the claim theory .{ }^{24}$ This opposition seems to imply that money can be understood either as a sign (and thus as a medium) ${ }^{25}$ or as a («singled out)) commodity. So, does media theory have to choose one side?

In the third part, it will be discussed that money is considered «neutral〉 in «neoclassical» standard theory - and what that means for a media theory of money.

In the fourth part, the results form the second and third parts are elaborated: a) the proposal is made to perceive commodities as media, insofar they carry signs of value, b) the question of the materiality and digitality of money is posed, and c) the perspective of a monetary media archaeology is sketched using an example.

The fifth part is a short conclusion.

\section{Commodity money and sign money}

Marx, who refers in the Outlines to money as a medium (as quoted above), also repeatedly employs concepts like 〈symbol〉 (close to 〈sign〉) for money, at least when it is in circulation: «Taking the whole circulation, therefore, 1 thaler represents 100 thaler, a weight of silver 100 times greater than it actually contains. In fact, it is merely a symbol of the weight of silver contained in the 100 thaler.» ${ }^{26}$ And:

«From this it follows that money as gold and silver, in so far as it serves merely as means of circulation, means of exchange, can be replaced by any other symbol that expresses a definite quantity of its unit. Hence symbolic money can replace real money because material money as mere means of exchange is itself symbolic.» ${ }^{27}$

Even though Marx's position is more complicated (as we will se below) and he specifically reserves the circulation sphere for the possibility that money can function as a sign, it is striking that he explicitly does not draw the conclusion that money is generally a sign:

«Marx $[. .$.$] went so far as to state that in circulation money became a mere symbol or$ token of value and capitalism was impossible without credit or credit money. Howev- 
er, he insisted that the primary function of money as the measure of value demanded a money commodity, typically gold [!]. Thus, Marx has been identified first and foremost in the tradition of commodity theorists of money.» ${ }^{28}$

Accordingly, it is stated in Capital:

«The act of exchange gives to the commodity converted into money, not its value, but its specific value form. By confounding these two distinct things some writers have been led to hold that the value of gold and silver is imaginary. The fact that money can, in certain functions, be replaced by mere symbols of itself, gave rise to that other mistaken notion, that it is itself a mere symbol. Nevertheless under this error lurked a presentiment that the money form of an object is not an inseparable part of that object, but is simply the form under which certain social relations manifest themselves. In this sense every commodity is a symbol, since, in so far as it is value, it is only the material envelope of the human labour spent upon it. But if it be declared that the social characters assumed by objects, or the material forms assumed by the social qualities of labour under the régime of a definite mode of production, are mere symbols, it is in the same breath also declared that these characteristics are arbitrary fictions sanctioned by the so-called universal consent of mankind.» ${ }^{29}$

For one thing, the idea that money is a «mere sign〉 is rejected here, because the exchange of goods does not generate value (here Marx's alleged «labour theory of value` shines through), ${ }^{30}$ but only the form in which the value is <expressed and actualized. ${ }^{31}$ If value would be generated in exchange, anything could in principle (see below for conditions like stability and digitality) be money - a consequence would be to declare the value of silver and gold to be simaginary> (and in a way that's it how we see it today).

Secondly, this view (according to which the «social characters assumed by objects, or the material forms assumed by the social qualities of labour under the regime of a definite mode of production, are mere symbols $)$ leads to regarding the social qualities of objects (thus being commodities) and the factual qualities of labour as <arbitrary fictions sanctioned by the socalled universal consent of mankind - meaning in today's words a 〈social construction〉.

Thirdly, it is implied that every commodity is a sign. I will discuss this issue in the fourth part of my paper. But before I will point to some theoretical problems in this discussion:

Marx apparently rejects the idea that the value of silver and gold is merely <imaginary> - this is consistent with the popular belief that Marx is a «metallist ${ }^{32}$ This leads to one of the oldest discussions in monetary theory - between metallism and nominalism: Does money have to 
consist of (mostly: metallic) things (or at least refer to them - as the final, central «money commodity) that 〈have value themselves〉 - or not (these would then be 〈mere〉 signs)? In light of the collapse of the gold bond after the First World War and ultimately after the end of Bretton Woods in 1973 the first standpoint is basically considered obsolete. It is often argued that the sign character of money has come to itself, so to speak, with this final end of the gold bond.

But the description of money as a sign raises the question of what the signs actually refer to (first problem of sign theory). In a first approximation - and quite corresponding to everyday experience - this can only be the 〈value〉, which however leads into the deep turmoil of theory (because: what is value?). ${ }^{33}$ Moreover Marx (or better: a certain Marx) seems to argue that sign-money only represents value or the «measure of value` embodied elsewhere (we presume in gold and silver as central money-commodities), 〈value〉 must be in some way intrinsic to these central commodities (otherwise they would be signs again). Or is there is simply no final stabilizing anchor? But we experience a certain stability of money...

The distinction of commodity money and sign money is very often equated with the distinction between metallism and nominalism, but does not seem to be quite identical to me. ${ }^{34} \mathrm{An}$ yway, the central question seems similar: the question is whether money must be a commodity or have commodity character, more precisely whether there is the already mentioned special money-commodity ${ }^{35}$ from which then monetary symbols derive their validity and stability, or not. According to a recent discussion, this money-commodity does not necessarily have to consist of precious metals; rather, it is the property titles deposited with the Central-Bank that are mentioned. ${ }^{36}$ The point seems to be ${ }^{37}$ that the money-commodity should guarantee the 〈coverage and stability of money. It is about the idea that there is «one sovereign commodity in which the value of all other commodities can be expressed once and for all..» ${ }^{38}$ It is therefore a matter of stabilizing the sign-function - and at the same time of emphasizing the continuity between money and commodities.

As is well known, Marx's formulaic description for the operations of capitalism was $\mathrm{M}-\mathrm{C}-$ $\mathrm{M}^{*}$ : Money is invested to produce (with recourse to labor) commodities that are sold for more money. Here another connection between commodities and money is implied, which is especially necessary to avoid another problem of pure sign theory of money (second problem of sign theory): If money, was «merely> arbitrarily fixed signs, for example by the state, ${ }^{39}$ why doesn't the state print more money and makes it available to everyone? Everyone would be rich! Awesome! However, there is at least the problem of inflation, of the failing stability of money, because the 〈value〉 of money itself would decrease (no matter which «nominal value〉 
is represented by the money sign) and every other commodity would get more and more expensive - so obviously there is a certain ontological continuity between commodities and money (that does not necessarily mean that we have to subscribe to monetarist theories according to which inflation is to be described as an asymmetry between the quantity of commodities and that of money).

From the point of view of of commodity theory, in a theory of signs, money stands as merely an external, 〈arbitrary product of reflection〉 opposite to 〈real economy〉 and its commodities (cf. III.), while commodity theory can think the inner connection between commodities and money (that is in a way deeper than mere arbitrary representation). Therefore, the idea of money as a medium (in analogy to other sign-forming media such as language) is criticized in this theoretical field. ${ }^{40}$ However - and here may lie a deconstructive way for media theory the contrast between commodity and sign theories is by no means so clear on closer inspection.

If money as a sign represents 〈value〉 and - according to Marx at the beginning of Capital things that are 'worth something), i.e. 〈have exchange value), are commodities - then money would be a commodity again. The difference between money-commodities and mere signs pointing to these becomes unclear. Or to put it slightly differently: The value of money as a commodity and even more the value of the central money commodity (if you presume one) has itself to be measured in money, although the value of money itself depends on the central money commodity. And moreover: property titles with the Central bank are obviously signs even if they act as the central money-commodity and therefore as a kind of special, stable, privileged sign. We could accept the idea that there is a privileged site that gives stability to the money-signs without assuming that these site doesn't consist of signs - they might be simply different signs. But it makes really sense to accept this idea, not of a central money commodity, but of a kind of central money-super-sign, a kind of transcendental signifier (Derrida), simply to avoid the two mentioned problems of sign theory of money.

There must be a kind of continuity between central money commodity and money signs, otherwise the money commodity could not be functionally represented by signs at all: The monetary symbols do not 〈merely〉 represent the money commodity, like the word 〈apple〉, which one cannot be eaten itself, represents an apple. Rather, they can function in the same way as the money commodity, as you can also exchange these signs for an apple (so it is questionable whether they really are 〈mere〉 signs). Additionally, the assumption that the special money commodity does not only have to cover (decken) its «mere〉 representatives, but can do so at all, points to a deeper connection between money signs and money commodity. 
Finally, it should be recalled that Marx, as quoted above, indicated that commodities could be understood as signs themselves: He emphasizes elsewhere that «The value of commodities is the very opposite of the coarse materiality of their substance, not an atom of matter enters into its composition ${ }^{41}$. Accordingly, the value is not 〈in the commodities, rather it can only be that the value is 〈attributed or 〈attached to a commodity, that it «expresses〉 or 〈represents〉 the value, which suggests a sign and even a media character of the good itself (I will come back to that in the fourth part.). In accordance to this, it is not easy to understand why silver and gold (or other alleged primordial money-commodities) should have value 〈per se (but one could argue: they are relatively rare and difficult to mine, so they embody a lot of labour value, if one wanted to get involved in a labour value theory; they are durable and therefore suitable as value storages; easily divisible and therefor potentially digital etc.), their physical materiality contains no 〈atom〉 of value, as Marx writes himself, value is obvious a kind of (social) sign process - Marx obviously cannot be described as a metallist in a simple sense.

\section{Money as a veil and as a neutral medium}

As already indicated, however, the continuity between goods and money is denied precisely by the dominant forms of economic theory. There is the division into a 〈real economy and the sphere of money (quite typical for sign theories), Hajo Riese can state:

«And it turns out that money remains an enigma for economic theory ( $\mathrm{Na}$ tionalökonomie) because this theory has not yet succeeded in deriving an independent monetary theory from the function of money in the economic process, but regards money as an addendum to a theory which can be formulated without it.» ${ }^{42}$

In neo-classical theories money is, as already mentioned above and often criticized, a neutral means that only facilitates exchange. In principle, one can also trade without money. Ganßmann states explicitly and critically about standard theory:

«Money is neutral. In fact, the whole architecture of economic theory since the marginal revolution of the late nineteenth century only makes sense if money is neutral. In general equilibrium theory, the core paradigm of modern economics, a moneyless but competitive market for goods and services is the unquestioned starting point of an axiomatic construction that includes money at best as an afterthought.» 43

For this reason alone, the neo-classical theory is not compatible with a media theory in which it is central, as Sybille Krämer emphasizes, that «media do not only serve the transmission of messages, but must rather be involved in the content of the messages themselves» ${ }^{44}$ - although the neo-classical theory with its nominalist, conventionalist sign theory of money initially appears as an ally. ${ }^{45}$ 
The assumption of the neutrality of money has been questioned many times - from Marx to Keynes to Ganßmann. ${ }^{46}$ In particular, Simmel's Philosophie des Geldes can be understood as an attempt to think (at least partially) of a non-neutral mediality of money. ${ }^{47}$ In order to understand the difference that this makes in media theory, it is necessary to clarify which historical ideas follow from these assumptions of standard economics (cf. Fig. 1).

\section{Gab es schon immer Geld?}

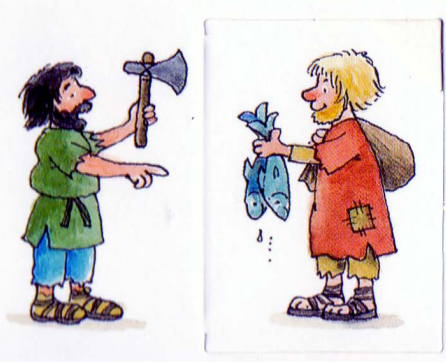

Bevor es Geld gab, haben die Menschen Waren gegen Waren getauscht. Das war schwierig, denn man fand nicht immer einen passenden Tauschpartner, der brauchte, was man selbst anzubieten hatte.

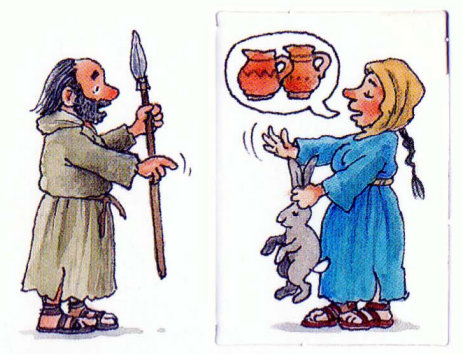

Oft waren sich die Menschen nicht einig über den Wert der Tauschgegenstände.
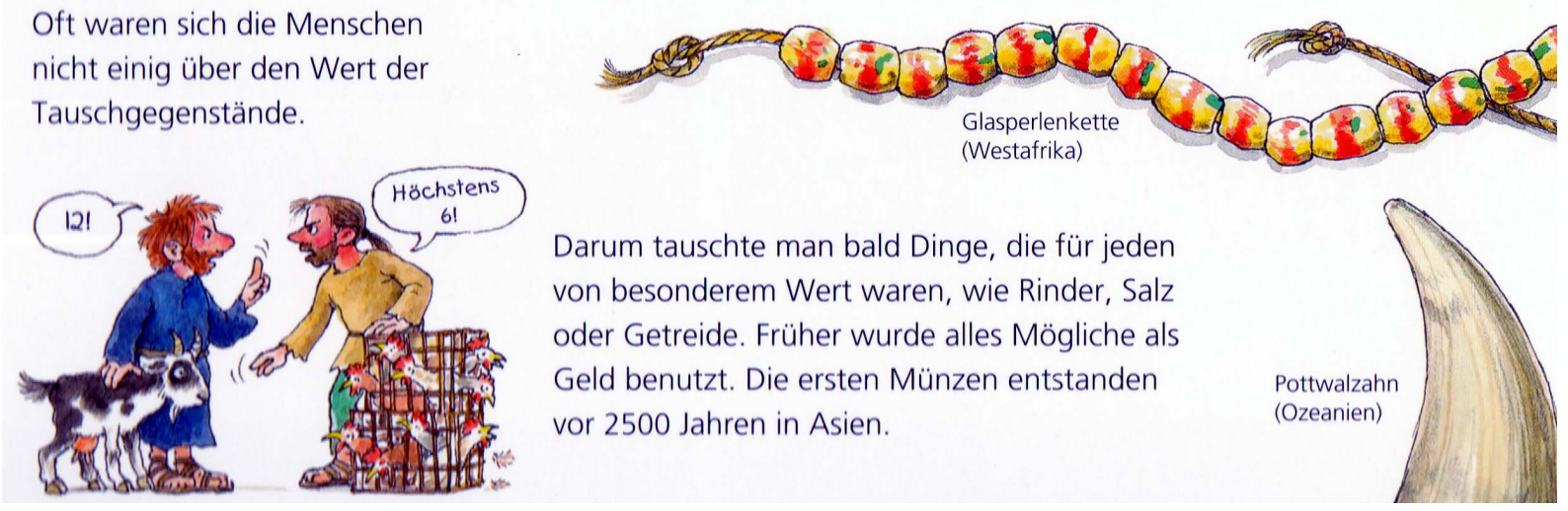

Darum tauschte man bald Dinge, die für jeden von besonderem Wert waren, wie Rinder, Salz oder Getreide. Früher wurde alles Mögliche als Geld benutzt. Die ersten Münzen entstanden vor 2500 Jahren in Asien.

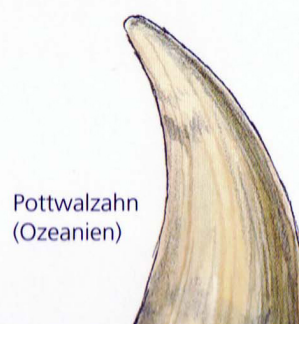

Fig. 1 Image from the children's book «Unser Geld und die Wirtschaft» [=〈Our money and the economy> Translation JS] about the alleged origin of money as a medium of exchange (orig. in colour).

A children's book (Fig. 1) ${ }^{48}$ shall be briefly mentioned here, because it is a good example of how certain economic ideas become hegemonic: They are already being inoculated into children. For example, it is problematically claimed that people have always produced separately from each other and then exchanged their products, i.e. ultimately exchanged them as commodities. ${ }^{49}$ It is concealed that there were very different economic forms (e.g. guilds, cooperatives, village communities, gifts, but also slavery; and even the existence of markets, which were diverse, does not mean that all society was market-shaped). Only the moneyless barter 
society that allegedly existed before money never existed, as the results of historical and anthropological research seem to show. ${ }^{50}$

One has to realize what this means: If there was moneyless barter at first and money «merely) «has been cunningly devised ${ }^{51}$ to make the process easier, then money has no momentum of its own. It would then only be a neutral means (which changes the exchange only in the sense that it facilitates, accelerates and expands it). And conversely, this means: In the children's book, as in hegemonic economics, the principle of contemporary society is extended ahistorically to all society and thus naturalized - the classic example of ideology. Moreover, research has shown that money could not have stabilized at all as a general yardstick in such an exchange process. ${ }^{52}$

But if money as a medium with its own dynamics is really taken seriously, then - in accordance with historical research - the «market [...] is not the source of money, but its product, a derivative of monetary relations, is not its origin». ${ }^{53}$ Or as Ingham puts it: «Large-scale multilateral exchange - that is, an authentic market - presupposes a stable standard of value expressed in a money of account. [...] That is to say, the very idea of money is logically anterior and historically prior to the market.» ${ }^{54}$ This is also covered by the fact that there was money long before capitalism and only with the begin of capitalism money became the central medium of social coordination. What this means in detail, why money (which is much older than (capitalism〉) did not automatically lead to the society-wide expansion of market form, whether there was and can be pre- and possibly post-capitalist money or not (or even a postmonetary society $)^{55}$, whether pre-capitalist money is money at all, cannot be discussed here. ${ }^{56}$ What is decisive is merely that a description of money as a medium in the sense of media theory is incompatible with certain assumptions about the neutrality of money.

\section{Elements of a Media Theory of Money}

After the necessarily brief (and in some respects incomplete) outline of positions on money in the second and third parts, one can now carefully deduce in which direction the media theory discussion could move.

a) Dissolving the dichotomy of sign and commodity theory of money: With a view to the discussion in the second part, it can be argued that the dichotomy between commodity theories and sign theories of money can possibly be dissolved in such a way that one follows Marx's hint - quoted above and actually meant critically: We could understand commodities as signs. Thus, Marx observes elsewhere that 
«[...] the natural distinctions between commodities must come into contradiction with their economic equivalence; the two can exist alongside one another only through the commodity acquiring a dual existence, a natural existence and alongside it a purely economic one, in which it is a mere sign, a letter for a relationship of production, a mere symbol for its own value. As value, every commodity is uniformly divisible; in its natural existence, it is not.» 57

Instead of arguing that money has to be commodities and not «mere signs» and then get into the problem that obviously operational money signs can be derived from a central money commodity (like gold f.e.), one could try to show that all commodities are signs for their value (however value is defined):

«In calculations, accountancy, etc., we are constantly transforming commodities into symbols of value, fixing them as mere exchange values, abstracting from their material composition and all their natural properties. On paper, in the head, this metamorphosis is produced by a simple process of abstraction; but in actual exchange a real mediation is necessary, a means by which this abstraction is effected.» 58

Even if this would have to be spelled out much more in historical detail, one can state that a certain constellation of mathematical, quantifying practices («calculating), 〈accounting), which presumably arose co-evolutively with money, ${ }^{59}$ casts a quantifying grid over all things and processes, which then assume sign character, a «mere symbol for its [the commodities] own value. ${ }^{60}$. That way, «physical things can only appear as commodities if they are in turn captured and defined by proportions». ${ }^{61}$ Accordingly, money is «one of the media in which the transition from the thing to the sign [is produced] ${ }^{62}$ and is itself (mostly) thing and sign at the same time: This process - referring the above quoted phrase <in calculations, accountancy, etc., we are constantly transforming commodities into symbols of value suggests - is decidedly performative, as Marx also emphasizes in a famous passage in Capital:

«Hence, when we bring the products of our labour into relation with each other as values, it is not because we see in these articles the material receptacles of homogeneous human labour. Quite the contrary: whenever, by an exchange, we equate as values our different products, by that very act, we also equate, as human labour, the different kinds of labour expended upon them. We are not aware of this, nevertheless we do it. Value, therefore, does not stalk about with a label describing what it is. It is value, rather, that converts every product into a social hieroglyphic.» ${ }^{63}$

Marx's famous formula $\mathrm{M}-\mathrm{C}-\mathrm{M}^{*}$ would thus be a process in which commodities become media for the reproduction and multiplication of value signs: «Money is originally the repre- 
sentative of all values; in practice it is the other way round, and all real products and all labour become representatives of money.» ${ }^{64}$

And with a view to the third part would have to be added: The spread of money and its centrality - however it may be historically described in detail- is by no means simply a continuation of simple exchange, but rather a profound semiotization and medialization, so to speak the primordial media economy. ${ }^{65}$

The media-theoretical perspective implied here thus neither asserts a contrast between commodity and sign money, nor does it make a central «money commodity〉 superfluous as a stabilizing mechanism for money signs. For precisely because the spread of money can be described as a process of medialization, the question of the stabilization of signs by reference to a central measure (money of account) and to state authority, which guarantees the validity of this measure (but not: the value that money has concretely relationally to all other goods), must play an important role (first stabilizing function: standardization). ${ }^{66}$ However, this perspective must theoretically be further elaborated in order to clarify whether phenomena such as the excessive ${ }^{67}$ accumulation in capitalism (no, not the greedy bankers, but everyday market economy is structurally excessive) can also be considered. It must also be asked to what extent the currently intensified discussions about (mediatization ${ }^{68}$ should be reassessed against this background - after all, money has always been used to mediatize things.

The position outlined here might come into conflict with all theories that want to draw a clear line between the media and all other entities ${ }^{69}$, since within the framework of the dominance of money all things, as long as they are commodities, are also medial. One can and must distinguish technologies which serve to transmit, process and store information from those which do not - but also the latter store and transfer as commodities information about their 〈value〉.

b) Materiality of money: What characteristics does the medium of money have, what constitutes its «moneyness» $?^{70}$ This question would perhaps be the first one would have expected from a media-theoretical approach to money. And the obvious question, at least from the point of view of a certain «German» media theory, would be the materiality of money. ${ }^{71}$ But precisely this seems problematic: money can occur in all possible forms, it seems that its history is essentially one of immaterialization, from metal money to paper money to online and mobile phone banking. So in an euphoric eulogy, typical of some 80s and 90s media theory, Hörisch wrote:

«See, the new media are making everything new. They liberate us from the dirty aspects that characterized the traditional media streams - from the printing ink, from the 
eucharistic blood stream, and also from the infamous materiality of the Pecunia olet money stream. The new communication relationships are immaterial. Pixels are largely free of earth gravity.» ${ }^{72}$

The materiality of money was declared to be of secondary importance already earlier: «One understands, then, that a change in the payment substance brings with it only minor disturbances; if the new substance is more convenient to handle than the old one, even everyone is glad that the change has occurred». ${ }^{73}$ Two things can be discussed: Firstly, is the materiality of the monetary symbols really so irrelevant? And secondly, is the teleological narrative according to which money (as an abstract form) comes to itself in immaterialization correct?

Obviously, the function of money under given conditions to operate as a store of value presupposes a certain stability of the medium - soap bubbles, for example, are unsuitable as currency: «a symbol, if it is not arbitrary, requires certain conditions as regards the material in which it is presented.» ${ }^{74}$ But this stability does not have to be localized in particularly durable materials, such as precious metals, as initially assumed. In the case of banknotes, for example, which are marked with elaborate security markings and where strict laws make any counterfeiting (or other «creative practices〉) punishable, stability and validity are created by the fact that they are difficult to counterfeit. In the case of pure booking money, such as online banking, the stability lies in the fact that access is secured with passwords, encryptions and the like, and that complex backup devices ensure that data is unconditionally retained, etc. Money is by no means becoming immaterial (today’s banking network infrastructures are more material than a pile of gold pieces), the materiality only changes: And it has the task of stabilizing above all the authenticity and validity of money - this is a technological condition of 〈trust) that money presupposes (second stabilizing function: technologies of trust). ${ }^{75}$ And money must obviously be countable, so both Seitter and Krämer speak of the structural digitality of money. ${ }^{76}$ One can thus understand the medialization through money described under a) as the digitization of all goods. This role of digital coding reappears in the field of the initially mentioned sociological media theories: «Money is the decisive and central medium that makes selections transferable» ${ }^{77}$ through a «computational $[\ldots]$ formalization.» ${ }^{78}$

c) Monetary media archaeology: A new media-historical perspective is emerging here, a monetary media archaeology ${ }^{79}$ that emphasizes above all that large parts of media history have already emerged under the «rule of money» ${ }^{80}$ (to this extent there is an 〈inner economy of the media $)^{81}$. This perspective has not yet been worked out, therefore no results can be presented here, only individual examples. 
The emphasis of such a monetary media archaeology would be, firstly, to examine how media are shaped by their attachment to the primordial media economy of money. For example, the current form of digital media and the containment of reproducibility by copyright and copy protection mechanisms etc. can only be understood as the shaping of digital technologies by their integration into a monetary economy of scarcity.

Secondly, it would have to examine at the same time how such processes of monetary formation can give rise to concepts of media that are shaped by money. In the ${ }^{82}$ following only one example shall be sketched: In 1859 the essay «The Stereoscope and the Stereograph» by Sir Oliver Wendell Holmes appears in the Atlantic Monthly ${ }^{83}$. The text is an enthusiastic account of the stereoscope that has existed since 1838, or to be more precise: of the use of stereoscopic photographs emerging soon after the invention. Holmes is enthusiastic about the three-dimensional impression of good stereoscopic images, which make it possible to travel from the comfortable armchair at home to foreign places. This text is interesting in many respects - but here only one aspect is emphasized, namely the final section of the essay. In it, Holmes wants to outline the possible future of the use of stereoscopic photographs. First he writes:

«Form is henceforth divorced from matter. In fact, matter as a visible object is of no great use any longer, except as the mould on which form is shaped. Give us a few negatives of a thing worth seeing, taken from different points of view, and that is all we want of it. Pull it down or burn it up, if you please.» ${ }^{84}$

Holmes further states that: «there must be arranged a comprehensive system of exchanges, so that there may grow up something like a universal currency of these bank-notes, or promises to pay in solid substance, which the sun has engraved for the great Bank of Nature.. ${ }^{85}$ The 〈banknotes〉 are the photographically detached forms of the objects. The circulation of the market has been taken into account: «Matter in large masses must always be fixed and dear; form is cheap and transportable. [...] Already a workman has been travelling about the country with stereographic views of furniture, showing his employer's patterns in this way, and taking orders for them. This is a mere hint of what is coming before long.» ${ }^{86}$

And finally, it is proposed to adapt the photographic images, the 〈banknotes to a standardized, formalized dimension that should allow equivalence between different forms:

« To render comparison of similar objects, or of any that we may wish to see side by side, easy, there should be a stereographic metre or fixed standard of focal length for the camera lens, to furnish by its multiples or fractions, if necessary, the scale of distances, 
and the standard of power in the stereoscope-lens. In this way the eye can make the most rapid and exact comparisons.»> 87

What is striking here is that first of all the <analogue photo is thought of in the terms of «digital〉 money and is understood through reference to exchange (as the effect of the form of money). Secondly, the aim of this digitization is to stabilize standardization and formalization, which will allow a kind of equivalent exchange. At any rate, this example illustrates how a new medium (here: the stereoscopic use of photographs) is conceived a priori in relation to the monetary medialization that has also formed all other objects (and processes) (at least) since the emergence of capitalism.

However, what is particularly interesting for the perspective of a monetary media archaeology, is that Holmes does not only think and describe (stereoscopic) photography in monetary terms, but ascribes to it a specific medial capacity. The «[...] greatest of human triumph over earthly conditions, the divorce of form and substance. ${ }^{88}$ conjured up by Holmes is central here: the detached forms should be able to replace the thing if necessary. As early as 1981, Allan Sekula noted in his essay "The Traffic in Photographs» that this passage described something typical for a capitalist society: «[...] just as use value is eclipsed by exchange value, so the photographic sign comes to eclipse its referent.» ${ }^{89}$ This can be understood as meaning that in a monetary economy only the exchange value is relevant, i.e. utility values are only produced if they can be sold - if there is no solvent demand, nothing is produced, regardless of whether the needs exist (a very well known phenomenon in th global south; the same amounts for ecological desaster, but that's another topic). Holmes' discourse reproduces this primacy of (exchange) form over (usable) matter. In a money-centered economy, objects are in the form of commodities, i.e. they transfer their exchange value as information. The commodity form has been a central way of transmitting information for several centuries.

Interestingly, Friedrich Kittler discusses Holmes' text based on the question «where the so untraditional concept of information, this reason and purpose of all technical media, comes from». ${ }^{90} \mathrm{He}$ argues that Holmes seems to be the first to consider media-technical information in his texts: «Under the age-old philosophic concept of form Holmes discusses modern information». ${ }^{91}$ Kittler does not deal with Holmes' monetary metaphors, but tries in the following (in an expectable way) to bind the concept of information to war. But if Holmes' discourse, shaped by monetary metaphors, is supposed to be the (or an?) ${ }^{92}$ origin of the concept of information, and expressly associates with it the predominance of the (exchange) form circulating on the market via (utility) matter and standardization and formalization for the formation of equivalents, then this concept of information is formed by money. However, it would be 
premature to causally deduce from this the above mentioned similarity between Kittler's definition of media as those techniques for «transmission, storage, processing of information» ${ }^{93}$ and the standard «money functions〉 as described by Issing (refer back to the first paragraph of my introduction)defined as standard today (namely money as a means of «exchange and payment» (transmission), «preserving value» (storage) and as an «unit of account» (processing). ${ }^{94}$ )

It is more likely that attention to questions of information, communication and thus mediality has at least one important root in the monetary economy. This connection also becomes clear in other media-theoretical traditions (albeit without recourse to Holmes). Thus, Niklas Luhmann states: «If one asks in the opposite direction where [the] view comes from that communication is a transmission of (valuable) information, it is obvious that it is unacknowledgedly oriented towards money». ${ }^{95}$

Both Kittler and Luhmann write at a time when economic theory has long since made information its central concept. ${ }^{96}$ Mirowski and Nik-Khah emphasize that the concept of information in economics does not derive primarily from Shannon, but from the so-called «socialist calculation debate> of the $1920 \mathrm{~s}$ and $1930 \mathrm{~s} .{ }^{97}$ This discussion has nothing to do with Holmes, but here - in addition to the above-mentioned use of the term «media» for money in the 19th century and Holmes - there is once again a source of concepts such as information, communication, medium that will be relevant for future media theories, a source of origin in which a term such as «knowledge» is understood above all in relation to monetary price signals. ${ }^{98}$ At least in Luhmann's forerunner Talcott Parsons, the reference to the economy as «the most important functional subsystem for modern industrial societies. $\gg{ }^{99}$ was still explicit. The aim of a monetary media archaeology must be, both in the development of the media themselves and in the emergence of their terms of reflection, to work out the hitherto underexposed history of economy and economics and thus, ultimately to make money visible again as the «medium par excellence» ${ }^{100}$.

\section{Conclusion}

Can media theory contribute something to the discussion about money that the other disciplines dealing with money (economics, sociology, political theory, philosophy) cannot do? This was the initial question to cut a path into the extremely complicated discussion about money.

In the second part, the classical opposition of commodity and sign theory of money was discussed. So it seems as if media theory, tending towards sign theories of money, has to reject commodity theory - and thus only duplicate the already existing theories. Firstly, this would 
not be a genuine perspective and secondly, it would take over the problems of sign theories. This was countered in a kind of deconstructive reading and it was shown that sign and commodity theories can possibly be understood as different formulations of a more fundamental media theory (referring to point a of part four).

In the third part, a central topic of the economic discussion and above all its critique had to be dealt with, namely that money is treated as neutral in large parts of economic theory, an assumption that is problematic from the point of view of media theory. Based on historical evidence, this assumption was rejected - money is not an effect of exchange practices, but rather their condition (at least on a larger scale).

In the fourth part, three different aspects of a possible genuine media theory of money, which of course still has to be worked out, were outlined:

a) Starting from the reading of the second part, it should be shown that the form of goods can only be understood as a sign and media form, because goods are things that simultaneously operate as a medium for signs of value (price). In media theory, the spread of commodity/money relationships can thus be understood as a fundamental medialization.

b) The central question in media theory about the materiality of the medium bearing the stamps can be answered provisionally in such a way that the money medium must essentially be characterized by various forms of stability and by digitality. The conventional narrative of increasing immaterialization is wrong - only the configurations of technologies of trust change.

c) From a) and b) the theoretical and historical task of a monetary media archaeology is sketched out. Of course, this remains to be carried out in detail.

\footnotetext{
${ }^{1}$ Karl Marx: Outlines of the Critique of Political Economy, in: Ibid., Frederick Engels: Collected Works, Vol. 28, New York 1986, 49-540, here 104.

${ }^{2}$ Carl Menger: The Origins of Money, in: Economic Journal, Vol. 2, Nr. 6, 1892, 239-255, here 241.

${ }^{3}$ Cf. Stefan Hoffmann: Geschichte des Medienbegriffs, Hamburg 2002.

${ }^{4}$ Friedrich Kittler: Draculas Vermächtnis. Technische Schriften, Leipzig 1993, 8. German original is: «Übertragung, Speicherung, Verarbeitung von Information»

${ }^{5}$ Monetary functions according to: Otmar Issing: Einführung in die Geldtheorie, 15. Aufl., München 2014, 1-2.

${ }^{6}$ Talcott Parsons: Sozialstruktur und die symbolischen Tauschmedien, in: Claus Pias et. al. (Ed.): Kursbuch Medienkultur. Die maßgeblichen Theorien von Brecht bis Baudrillard, 4. Aufl., Stuttgart 1999, 34-44, here 34 [English original has to be located]. Parson's examination of money will later decisively influence Niklas Luhmann's theory of money, cf. Niklas Luhmann: Die Wirtschaft der Gesellschaft, Frankfurt / M. 1988, Kap. 7.
} 
${ }^{7}$ Cf. Marshall McLuhan: Understanding Media. The Extensions of Man. Critical Ed., Berkeley, CA 2015 ( $3^{\text {rd }}$ Printing), Chapter $14 \& 33$.

${ }^{8}$ Using the example of Understanding Media cf. Jens Schröter in particular: Von Heiß / Kalt zu Analog / Digital. Die Automation als Grenze von McLuhans Medienanthropologie, in: Derrick de Kerckhove et. al. (Ed.): McLuhan neu lesen. Kritische Analysen zu Medien und Kultur im 21. Jahrhundert, Bielefeld 2008, 304-320.

${ }^{9}$ McLuhan: Understanding Media, 85.

${ }^{10}$ McLuhan: Understanding Media, 186.

${ }^{11}$ Marshall McLuhan: Living at the Speed of Light, in: ibid.: Understanding Me. Lectures and Interviews, published by Stephanie McLuhan \& David Staines, Cambridge, Mass. 2005, 225-243, here 243.

${ }^{12}$ This suspicion has already been formulated by Dierk Spreen: Tausch, Technik, Krieg. Die Geburt der Gesellschaft im technisch-medialen Apriori, Berlin, Hamburg 1998, especially Chapter 1.

${ }^{13}$ Hartmut Winkler: Münzen \& Zeichen, Diskursökonomie und Geld. Ein Gespräch, in: Der Schnitt. Das Filmmagazin, Nr. 41, 2006, 22-25, here 23. German original is: «Überschneidungsbereich».

${ }^{14}$ Jochen Hörisch: Geld, in: Jens Schröter (Ed.): Handbuch Medienwissenschaft, Stuttgart 2014, 239-244, here 239.

${ }^{15}$ Cf. e.g. Walter Seitter: Die Physik der Medien. Materialien, Apparate, Präsentierungen, Weimar 2002, 179-196; Jochen Hörisch: Gott. Geld, Medien. Studien zu den Medien, die die Welt im Innersten zusammenhalten, Frankfurt / M. 2004; Hartmut Winkler: Diskursökonomie. Versuch über die innere Ökonomie der Medien, Frankfurt / M. 2004, 36-50.

${ }^{16}$ This term is summarical and inaccurate, since, for example, certain elements of Keynesian theory were adopted after 1945. Cf. David Colander, Richard P. F. Holt, J. Barkley Rosser: The Changing Face of Mainstream Economics, in: Review of Political Economy, Vol. 16, Nr. 4, 2004, 485-499.

${ }^{17}$ Cf. Hanno Pahl: Das Geld in der modernen Wirtschaft. Marx und Luhmann im Vergleich, Frankfurt / M., New York 2008, 9-16; Hajo Riese: Geld - die unverstandene Kategorie der Nationalökonomie, in: Ethik und Sozialwissenschaften. Streitforum für Erwägungskultur, Vol. 11, Nr. 4, 2000, 487-498.

${ }^{18}$ Cf. Frederic Lee: A History of Heterodox Economics. Challenging the Mainstream in the Twentieth Century, New York 2009 and Philip Arestis, Malcolm Sawyer (Ed.): A Handbook of Alternative Monetary Economics, Cheltenham, Northampton 2006.

${ }^{19} \mathrm{Cf}$. Geoffrey Ingham (Ed.): Concepts of Money. Interdisciplinary Perspectives from Economics, Sociology and Political Science, Cheltenham, Northhampton 2005. Cf. on the history of economic knowledge Joseph Vogl: Das Gespenst des Kapitals, Zürich 2010. [English Version has to be mentioned here]

${ }^{20}$ Cf. Georg Simmel: Philosophie des Geldes, Leipzig 1900. [English Version has to be mentioned here]

${ }^{21}$ Nevertheless, cf. Michael Hutter: Signum non olet: Grundzüge einer Zeichentheorie des Geldes, in: Waltraud Schelkle, Manfred Nitsch (Ed.): Rätsel Geld. Annäherungen aus ökonomischer, soziologischer und historischer Sicht, Marburg 1995, 325-352. The perception of 
money as a medium and / or sign is criticized fundamentally in Karl-Heinz Brodbeck: Die Herrschaft des Geldes. Geschichte und Systematik, Darmstadt 2009, 363-366 \& 369-371.

${ }^{22} \mathrm{Cf}$. on the problems of defining media studies and subsequently media theory Ulrike Bergermann: Leere Fächer. Gründungsdiskurse in Kybernetik und Medienwissenschaft, Münster 2015 and Jens Schröter: Einleitung, in: ibid. (Ed.): Handbuch Medienwissenschaft, Stuttgart 2014, 1-11.

${ }^{23}$ Heiner Ganßmann: Geld - ein symbolisch generalisiertes Medium der Kommunikation? Zur Geldlehre in der neueren Soziologie, in: Prokla 63, Vol. 16, Nr. 2, 1986, 6-22, here 8. ${ }^{24}$ Ingham: Concepts of Money, xi. Claim theory refers to, what in the following will be called «sign theory〉 of money. Cf. Joseph A. Schumpeter: Das Wesen des Geldes, Göttingen 1970, $42 \&$ passim. Cf. on the attempt to mediate the positions Tony Lawson: Social Positioning and the Nature of Money, in: Cambridge Journal of Economics, Vol. 40, Nr. 4, 2016, 961996.

${ }^{25}$ The connection between signs and media is not a trivial problem. In order to not unnecessarily inflate the argumentation here, it shall be permitted to interpret the «sign theory of money as the «media theory > money, cf. Hartmut Winkler: Zeichenmaschinen. Oder warum die semiotische Dimension für eine Definition der Medien unerlässlich ist, in: Stefan Münker, Alexander Roesler (Ed.): Was ist ein Medium?, Frankfurt / M. 2008, 211-221.

${ }^{26}$ Marx: Outlines, 144.

${ }^{27}$ Ibid., 147.

${ }^{28}$ Anitra Nelson: Marx's Objections to Credit Theories of Money, in: Fred Moseley (Ed.): Marx's Theory of Money. Modern Appraisals, Basingstoke, New York 2005, 65-77, here 66, italics, JS.

${ }^{29}$ Karl Marx: Capital. A Critique of Political Economy, in: Karl Marx, Frederick Engels: Collected Works. Vol. 35, New York 1996, 101-102.

${ }^{30}$ Whether Marx really opted for a labour value theory or rather critically 〈deconstructed the labour value theories of economic classicism (Smith, Ricardo) cannot be discussed here, the author is inclined to the second idea.

${ }^{31}$ For the virtuality of value, cf. Harald Strauß: Signifikationen der Arbeit. Die Geltung des Differenzianten 〈Wert〉, Berlin 2013, 275-277.

${ }^{32}$ Cf. critically: Nelson: Marx's Objections, and Suzanne de Brunhoff: Marx on Money, New York 1976, 126-128.

${ }^{33}$ The formation of economic theory since the «marginalistic revolution〉 has value declared obsolete and operates only with prices (also due to the so-called transformation problem with Marx, cf. e.g. Michael Heinrich: Die Wissenschaft vom Wert. Die Marxsche Kritik der politischen Ökonomie zwischen wissenschaftlicher Revolution und klassischer Tradition, 5th Ed., Münster 2011, 267-269). However, this averting from value is theoretically unstable (as Strauß: Signifikationen, 17-19) and many others argue.

${ }^{34}$ Already, cf. Ludwig von Mises: Zur Klassifikation der Geldtheorien, in: Archiv für Sozialwissenschaft und Sozialpolitik, Vol. 44, 1917/1918, 198-213. Cf. Das Wesen des Geldes.

${ }^{35} \mathrm{Cf}$. on the problem of a central money commodity e.g. Ansgar Knolle-Grothusen, Stephan Krüger, Dieter Wolf: Geldware, Geld und Währung. Grundlagen zur Lösung des Problem der Geldware, Hamburg 2009. Cf. also Heinrich: Wissenschaft vom Wert, 233-235, who denies the necessity of a central money commodity. 
${ }^{36}$ Such as Ernst Lohoff: Auf Selbstzerstörung programmiert. Über den inneren Zusammenhang von Wertformkritik und Krisentheorie in der Marx'schen Kritik der Politischen Ökonomie, in: Krisis, Nr. 2, 2013, 50, online at: www.krisis.org/wpcontent/data/krisis zwei2013.pdf, last seen on 12.9.2017.

${ }^{37}$ Cf. Ernst Lohoff: Auf Selbstzerstörung programmiert, $48 \mathrm{f}$.

${ }^{38}$ Frederick Engels: Anti-Dühring. Herr Eugen Dühring's Revolution in Science, in: Karl Marx, ibid.: Collected Works, Vol. 25, New York 1987, 5-298, here 293.

${ }^{39}$ Sign theories of money mostly imply so-called chartalistic positions according to which money is essentially defined by the state. Cf. as a key text Georg Friedrich Knapp: Staatliche Theorie des Geldes, Munich, 4th edition, Leipzig 1923.

${ }^{40}$ Cf. Marx: Outlines, 99. Cf. also Heiner Ganssmann (= Ganßmann): Doing Money. Elementary Monetary Theory from a Sociological Standpoint, New York 2012, 20-34 \& ibid.: Geld for a detailed critique of sociological approaches (Parsons, Habermas, Luhmann).

${ }^{41}$ Marx: Capital, 57.

${ }^{42}$ Riese: Geld, 489. Cf. also Tobias Kohl: Geld und Gesellschaft. Zu Entstehung, Funktionsweise und Kollaps von monetären Mechanismen, Zivilisation und sozialen Strukturen, Marburg 2014, 76-80.

${ }^{43}$ Ganssmann: Doing Money, 14.

${ }^{44}$ Sybille Krämer: Das Medium als Spur und als Apparat, in: ibid. (Ed.): Medien Computer Realität. Wirklichkeitsvorstellungen und Neue Medien, Frankfurt / M. 1998, 73-94, here 73. ${ }^{45}$ On the nominalistic character of dominant monetary theory cf. Hans-Georg Backhaus: Dialektik der Wertform. Untersuchungen zur Marxschen Ökonomiekritik, Freiburg 1997, 80-82. ${ }^{46}$ Cf. e.g. Ganssmann: Doing Money and on Keynes Maria Cristina Marcuzzo: The «Cambridge> Critique of the Quantity Theory of Money: A Note on How Quantitative Easing Vindicates It, in: Journal of Post-Keynesian Economics, Vol. 40, Nr. 2, 2017, 260-271.

${ }^{47}$ Cf. Paschen von Flotow: Geld, Wirtschaft und Gesellschaft. Georg Simmels Philosophie des Geldes, 2nd Ed., Frankfurt / M. 2016, especially chapter 3.

${ }^{48}$ Image from: Angela Weinhold: Unser Geld und die Wirtschaft, Ravensburg 2015. Thanks to Till A. Heilmann and Anna Tuschling.

${ }^{49}$ Cf. Marx: Capital, 52: «Only such products can become commodities with regard to each other, as result from different kinds of labour, each kind being carried on independently and for the account of private individuals.».

${ }^{50}$ Cf. David Graeber: Schulden. Die ersten 5000 Jahre, Stuttgart 2012, 27-49.

${ }^{51}$ Karl Marx: A Contribution to the Critique of Political Economy. Part One, in: Ibid., Frederick Engels: Collected Works, Vol. 29, New York 1975, 257-417, here 291.

${ }^{52}$ Cf. Ingham: The Nature of Money, Cambridge, Malden, Mass. 2004, $24 \mathrm{f}$.

${ }^{53}$ Kohl: Geld und Gesellschaft, 283.

${ }^{54}$ Ingham: Concepts of Money, xvii. Cf. Axel Paul: Die Gesellschaft des Geldes. Entwurf einer monetären Theorie der Moderne, Wiesbaden 2004, 50, who explicitly states that money is a condition for functional differentiation (in Luhmann's sense).

${ }^{55}$ Cf. also Heidenreich: Geld. Für eine non-monetäre Ökonomie, Berlin 2017.

${ }^{56} \mathrm{Cf}$. on pre-capitalist money and the changes in money due to the transition to capitalism Graeber: Schulden; Ingham: Nature of Money, Kap. 5 u. 6; Jacques Le Goff: Geld im Mittelalter, Stuttgart 2011. 
${ }^{57}$ Marx: Outlines, 79.

${ }^{58}$ Ibid., 80 - said «means〉 is money.

${ }^{59}$ Cf. Robert A. Bryer: The History of Accounting and the Transition to Capitalism in England. Part One: Theory, in: Accounting, Organizations and Society, Vol. 25, Nr. 2, 2000, 131162.

${ }^{60}$ Marx: Outlines, 79.

${ }^{61}$ Karl-Heinz Brodbeck: Philosophie des Geldes, in: Wolf Dieter Enkelmann, Birger Priddat (Eds.): Was ist? Wirtschaftsphilosophische Erkundungen, Marburg 2014, 45-76, online at www.khbrodbeck.homepage.t-online.de/philgeld.pdf, last seen 16.9.2017. Cf. Engster: Das Geld als Maß, Mittel und Methode. Das Rechnen mit der Identität der Zeit, Berlin 2014 on the central role of measuring concerning money.

${ }^{62}$ Seitter: Physik der Medien, 182.

${ }^{63}$ Marx: Capital, 85.

${ }^{64}$ Marx: Outlines, 87.

${ }^{65}$ On value and semiosis, cf. Strauß: Signifikationen.

${ }^{66}$ Cf. Engster: Das Geld als Maß and Oliver Schlaudt: Marx als Messtheoretiker, in: Werner Bonefeld, Michael Heinrich (Eds.): Kapital \& Kritik. Nach der «neuen» Marx-Lektüre, Hamburg 2011, 258-280.

${ }^{67}$ Cf. Marx: Capital, 163: „The circulation of capital has therefore no limits.“

${ }^{68}$ Cf. perhaps Stig Hjarvard: The Mediatization of Culture and Society, London 2013.

${ }^{69}$ Cf. Hartmut Winkler: Jenseits der Medien. Über den Charme der stummen Praxen und einen verdeckten Wahrheitsdiskurs, in: Eike Hebecker, Frank Kleemann, Harald Neymanns (Eds.): Neue Medienumwelten, Frankfurt / M., New York 1999, 44-61.

${ }^{70}$ Ingham: Concepts of Money, xi. Ultra-nominalistic answers like «Geld ist, was Geldfunktionen ausübt» (Issing: Geldtheorie, 3) are theoretically unusable because of their circularity. ${ }^{71}$ The focus on 〈german> media theoretical discussion can be explained by the fact that this discussion has placed a special emphasis on the materiality and technicity of media - and therefore has difficulties with money in its changeable forms.

${ }^{72}$ Hörisch: Gott, Geld, Medien, 170.

${ }^{73}$ Knapp: Staatliche Theorie des Geldes, 15. Cf. also Alfred-Sohn Rethel: Das Geld, die bare Münze des Apriori, Berlin 1990, 34.

${ }^{74}$ Marx: Outlines, 83.

${ }^{75}$ Cf. Karl de Leeuw, Jan Bergstra (Hg.): The History of Information Security: A Comprehensive Handbook, Amsterdam et.al. 2007. Cf. Jens Schröter: Das mediale Monopol des Staates und seine Verteidigungslinien, in: Zeitschrift für Medien- und Kulturforschung, Vol. 6, Nr. 2, 2015, 13-24. Cf. additionally Seitter: Physik der Medien, 189-190 and Winkler:

Diskursökonomie, 39, who in turn underline the irreducible materiality of money.

${ }^{76}$ Seitter: Physik der Medien, 181 and Sybille Krämer: Das Geld und die Null: Die Quantifizierung und die Visualisierung des Unsichtbaren in Kulturtechniken der frühen Neuzeit, in: Klaus W. Hempfer, Anita Traninger (Eds.): Macht Wissen Wahrheit, Freiburg, Berlin 2005, 79-100.

${ }^{77}$ Talcott Parsons: Zur Theorie der sozialen Interaktionsmedien. Herausgegeben und eingeleitet von Stefan Jensen, Opladen 1980, 32 (from Jensen's introduction).

${ }^{78}$ Luhmann: Wirtschaft, 242. 
${ }^{79} \mathrm{Cf}$. on the programmatic background to this formulation Jens Schröter, Till A. Heilmann: Zum Bonner Programm einer neokritischen Medienwissenschaft. Statt einer Einleitung, in: ibid. (Eds.): Medienwissenschaft und Kapitalismuskritik (= Navigationen, Vol. 16, Nr. 2, 2016), Siegen 2016, 7-36.

${ }^{80} \mathrm{Vgl}$. Brodbeck: Herrschaft.

${ }^{81}$ Cf. Winkler: Diskursökonomie.

${ }^{82}$ If the commodity form itself determines the form of thought, as Sohn-Rethel claimed. Cf. ibid.: Geld.

${ }^{83}$ Cf. Oliver Wendell Holmes: The Stereoscope and the Stereograph, in: Atlantic Monthly, Vol. 3, Nr. 20, June 1859, Online at:

https://www.theatlantic.com/magazine/archive/1859/06/the-stereoscope-and-thestereograph/303361/, last seen 1.8.2019.

${ }^{84}$ Ibid.

${ }^{85}$ Ibid.

${ }^{86}$ Ibid.

${ }^{87}$ Ibid.

${ }^{88}$ Ibid.

${ }^{89}$ Allan Sekula: The Traffic in Photographs. in: Art Journal, Vol. 41, No. 1, Photography and the Scholar/Critic (Spring, 1981), College Art Association 1981, 15-25, here 22, Online at: http://www.jstor.org/stable/776511, last seen 1.8.2019.

${ }^{90}$ Cf. Friedrich Kittler: Optische Medien. Berliner Vorlesung 1999, Berlin 2002, 39. [englisch translation]

${ }^{91}$ Ibid.

${ }^{92} \mathrm{Cf}$. On the history of the concept of information Bernard Dionysius Geoghegan: The Historiographic Conceptualization of Information: A Critical Survey, in: IEEE Annals of the History of Computing, Vol. 30, Nr. 1, 2008, 66-81.

${ }^{93}$ Kittler: Draculas Vermächtnis, 8.

${ }^{94}$ Issing: Einführung in die Geldtheorie, $1 \mathrm{f}$.

${ }^{95}$ Luhmann: Wirtschaft, 246.

${ }^{96}$ Cf. Philip Mirowski, Edward Nik-Khah: The Knowledge We Have Lost in Information. The History of Information on Modern Economics, New York 2017.

${ }^{97}$ Cf. Ibid., 60-66.

${ }^{98}$ Exemplary: Friedrich August von Hayek: Die Verwertung des Wissens in der Gesellschaft, in: ibid. Gesammelte Schriften in deutscher Sprache, issued by Alfred Bosch et. al., Dept. A, Vol. 1, Wirtschaftstheorie und Wissen. Aufsätze zur Erkenntnis- und Wissenschaftslehre, Tübingen 2007, 57-70.

${ }^{99}$ Parsons: Interaktionsmedien, 24 (from the introduction by Jensen). See Talcott Parsons, Neil J. Smelser: Economy and Society. A Study in the Integration of Economic and Social Theory, New York 1956, 11 zur «significance of information in economic processes». Hayek isn't mentioned there.

${ }^{100}$ Niklas Luhmann: Die Gesellschaft der Gesellschaft, Frankfurt / M. 1997, 723. 